\title{
Distinct Matters between the Phenomenon of Smuggling of Migrants and Trafficking in Human Beings as Types of Organized Crime in Kosovo
}

\author{
M.Sc. Armend Podvorica, PhD Cand. \\ Lecturer at the University of Prizren "Ukshin Hoti" \\ Lecturer at the University of Prishtina "Hasan Prishtina" branch Ferizaj \\ Contact: +377 (0) 44163311, email: armendi_537@hotmail.com
}

\begin{abstract}
Generally speaking, the organized crime is a very complex phenomenon and quite heterogenic that adapts to the various requirements of economy and political and social institutions of the countries where it emerges and operates. Subject to the criteria that are taken as basis for its classification, the criminal phenomena emerge and operate in various types of organized crime. Hence, the Republic of Kosovo has introduced punishments against the organized criminal groups and major types of crime that emerge and expand in the shape of organized crime, including smuggling of migrants and trafficking in human beings. The criminal phenomena in the form of organized crime in the modern world which appears to be very concerning and quite threatening for the whole society, is trafficking in human beings and smuggling of migrants. Therefore, it is very important to study and identify all matters which bring together and separate these two criminal phenomena, which have emerged and continue to be present in various places and countries throughout continents and that have caused fundamental political, social, economic, cultural changes, etc. The key matters to be treated are as follows: Legal Framework of Republic of Kosovo which treats and punishes the organized crime, smuggling of migrants and trafficking in human beings, including the distinct points between these two criminal offences.
\end{abstract}

Keywords: distinct matters, smuggling, migrants, trafficking, human beings, organized crime, Kosovo

\section{Introduction}

In general, the organized crime is a very complex phenomenon and quite heterogenic that adapts to the various requirements of economy and political and social institutions of the countries where it emerges and operates. Subject to the criteria that are taken as basis for classification, the criminal phenomena emerge and operate in various types of organized crime.

The criminal legal literature by majority of authors has treated the following criminal phenomena as a type of organized crime: trafficking in human beings, smuggling of migrants, narcotics, weapons, nuclear materials, terrorism, thefts and vehicle smuggling, gambling, etc.

The Criminal Code of Kosovo of $2012^{1}$, under chapter XXIV, punishes the organized crime, respectively its article 283 introduces the criminal offense "Participation in or organization of an organized criminal group" which provides as follows:

1. Whoever, with the intent and with knowledge of either the aim and general activity of the organized criminal group or its intention to commit one or more criminal offenses which are punishable by imprisonment of at least four (4) years, actively takes part in the group's criminal activities knowing that such participation will contribute to the achievement of the group's criminal activities, shall be punished by a fine of up to hundred fifty thousand $(250,000)$ EUR and imprisonment of at least seven (7) years.

\footnotetext{
${ }^{1}$ Criminal Code of Kosovo, Kosovo Assembly, Prishtinë, 2011, Code No. 04/L-082 which took effect on 20th April 2012.
} http://www.kuvendikosoves.org/?cid=1,122 
2. Whoever organizes, establishes, supervises, manages or directs the activities of an organized criminal group shall be punished by a fine of up to five hundred thousand $(500,000)$ EUR and by imprisonment of at least ten (10) years.

3. When the activities of the organized criminal group provided for in paragraph 1 or 2 of this Article result in death, the perpetrator shall be punished by a fine of up to five 149 hundred thousand $(500,000)$ EUR and by imprisonment of at least ten (10) years or life long imprisonment.

4. The court may reduce the punishment of a member of an organized criminal group who, before the organized criminal group has committed a criminal offense reports to the police or prosecutor the existence, formation and information of the organized criminal group in sufficient detail to allow the arrest or the prosecution of such group.

5. For the purposes of Article, "actively takes part" includes, but is not limited to, the provision of information or material means, the recruitment of new members and all forms of financing of the group's activities.

The criminal phenomena in the form of organized crime in the modern world which appears to be very concerning and quite threatening for the whole society, is trafficking in human beings and smuggling of migrants. These criminal phenomena have emerged and continue to be present in various places and countries throughout continents and these have caused fundamental political, social, economic, cultural changes, etc.

The present study reveals that with reference to certain cases, one cannot make a distinction between the criminal offence of smuggling of migrants and the criminal offence of trafficking in human beings, or one finds it difficult to make such a distinction. Thus, it is important to point out their constituent elements which make it possible to easily identify the distinction between these two criminal offenses. Kosovo and its population, during the period 1989 - 1999 have experienced the biggest flux of migration in its history ${ }^{1}$, where almost each family in Kosovo had either one member or more abroad due to the difficult political and economic situation ruling in the country. In order to observe the distinct points between these two criminal offenses, it is important to provide the definition of criminal offense of Smuggling of migrants and Trafficking in human beings.

The paragraph 8 , article 170 of the Criminal Code of Kosovo, respectively paragraph 8.1 stipulates as follows:

8.1. The definition "Smuggling of migrants" - means any action with the intent to obtain, directly or indirectly, a financial or other material benefit, from the illegal entry of a person into the Republic of Kosovo, where such person is not a Republic of Kosovo National, or a person who is a Republic of Kosovo National or a foreign national into a State in which such person is not a permanent resident or a citizen of such State.

8.2. The definition "Illegal entry" - means crossing a border or a boundary of the Republic of Kosovo without complying with the necessary requirements for legal entry into the Republic of Kosovo or crossing the borders of a State without complying with the necessary requirements for legal entry into such State.

8.3. The definition "Fraudulent travel or identity document" means any travel or identity document:

8.3.1. that has been falsely made or altered in some material way by any person other than a person or agency lawfully authorized to make or issue the travel or identity document;

8.3.2. that has been improperly issued or obtained through misrepresentation, corruption or duress or in any other unlawful manner; or

8.3.3. that is being used by a person other than the rightful holder. ${ }^{2}$

This definition is similar with the definition set forth under article $3{ }^{3}$ of the Protocol against Smuggling of Migrants by Land, Sea and Air, supplementing the United Nations Convention against Transnational Organized Crime.

\footnotetext{
${ }^{1}$ Baton Haxhiu. Lufta ndryshe (War Differently)(.Prishtinë, 2004, p. 69.)

2 Criminal Code of Kosovo, 2011, article 170.

${ }^{3}$ According to article 3 of the Protocol: (a)"Smuggling of migrants" shall mean the procurement, in order

to obtain, directly or indirectly, a financial or other material benefit, of the illegal entry of a person into a State Party of which the person is not a national or a permanent resident 
Although these two criminal offenses are similar between each other, again, they contain elements, on the grounds of which a distinction can be made. The Article 171 of the Criminal Code of Kosovo, respectively paragraph 6.1 provides: the definition "trafficking in persons" means the recruitment, transportation, transfer, harboring or receipt of persons, by threat or the use of force or other forms of coercion, abduction, fraud, deception, the abuse of power or the abuse of a position of vulnerability or the giving or receiving of payments or benefits to achieve the consent of a person having control over another person, for the purpose of exploitation.

6.2. the definition "exploitation" as used in sub-paragraph 6.1 of this paragraph shall include, but not be limited to, prostitution of others, pornography or other forms of sexual exploitation, begging, forced or compulsory labour or services, slavery or practices similar to slavery, servitude or the removal of organs or tissue.

6.3. The consent of a victim of trafficking in persons to the intended exploitation shall be irrelevant where any of the means set forth in sub-paragraph 6.1. of this paragraph have been used against such victim.

6.4. The recruitment, transportation, transfer, harboring or receipt of a child for the purpose of exploitation shall be considered "trafficking in persons" even if this does not involve any of the means set forth in subparagraph 6.1. of this paragraph.

This term is similar with definition set forth under article $3^{1}$ of the Protocol to Prevent, Suppress and Punish Trafficking in Persons, Especially Women and Children, that was adopted in November 2000 and that served as the main source to draw up national laws against trafficking.

By performing an analysis to the aforementioned articles, in specific, to the provided definitions, we can identify the distinct points between the criminal offense of smuggling of migrants and the criminal offense of trafficking in human beings, as follows:

1. Establishment of relations between the trafficker and the victim. In the case of trafficking, this relation is established and exists only until such person is transferred to the place of destination, i.e. to emigrate, and afterwards it ceases to exist. Whereas, in the case of trafficking, this relation continues further through exploitation for the purposes of benefit.

2. The object of a criminal offense in trafficking is called victim, while in smuggling it is called a migrant, so it is not called a victim;

3. In the case of criminal offense of trafficking, the victim's consent is voluntary in most of the cases (in certain cases due to failure in rehabilitation and reintegration of the victim in the society, the ex-victim willingly becomes a victim of the criminal offense of trafficking, but in the majority of cases such willingness is obtained through various methods such as for instance fraud, force, etc. Whereas, in the case of smuggling, the migrant consents willingly to such offense;

(b) "lllegal entry" shall mean crossing borders without complying with the necessary requirements for legal entry into the receiving State;

(c)"Fraudulent travel or identity document" shall mean any travel or identity document:

(i) That has been falsely made or altered in some material way by anyone other than a person or agency lawfully authorized to make or issue the travel or identity document on behalf of a State; or

(ii) That has been improperly issued or obtained through misrepresentation, corruption or duress or in any other unlawful manner; or

(iii) That is being used by a person other than the rightful holder;

${ }^{1}$ Article 3 of the Protocol to Prevent, Suppress and Punish Trafficking in Persons, especially Women and Children, UN, 2000.

a) "Trafficking in persons" shall mean the recruitment, transportation, transfer, harbouring or receipt of persons, by means of the threat or use of force or other forms of coercion, of abduction, of fraud, of deception, of the abuse of power or of a position of vulnerability or of the giving or receiving of payments or benefits to achieve the consent of a person having control over another person, for the purpose of exploitation. Exploitation shall include, at a minimum, the exploitation of the prostitution of others or other forms of sexual exploitation, forced labour or services, slavery or practices similar to slavery, servitude or the removal of organs;

b) The consent of a victim of trafficking in persons to the intended exploitation set forth in subparagraph (a) of this article shall be irrelevant where any of the means set forth in subparagraph (a) have been used;

c) The recruitment, transportation, transfer, harbouring or receipt of a child for the purpose of exploitation shall be considered "trafficking in persons" even if this does not involve any of the means set forth in subparagraph (a) of this article;

d) "Child" shall mean any person under eighteen years of age. 
4. For the criminal offense of smuggling of migrants to exist, it is necessary to cross a state border. On the other hand, the offense of trafficking in human beings may take place within the state boundaries.

5. Smuggling is a criminal offense against the judicial system which enforces the public order of management and control of state boundaries, whereas trafficking is a criminal offense against freedom, dignity and personality of an individual.

6. In the case of smuggling, the initiative/request to commit a criminal offense of smuggling arises from the migrant, so it is the migrant who seeks certain services from the smuggler to cross the border, whereas in the case of trafficking, it is the trafficker who through use of coercion, misinterpretation or otherwise, commits migration, respectively trafficking, and this does not depend on the victim's choice.

7. The purpose of movement of a migrant in the case of smuggling is to cross a border, whereas in the case of trafficking, its purpose is to take a victim in a foreign environment without protection and exploration as rational as possible.

The smuggling of migrants can easily be converted into trafficking in human beings. In fact, the smuggling of migrants who are women and children should be treated as trafficking in human beings, due to possibility of their abuse and exploitation. The importance of distinction of concepts between these two criminal phenomena is connected with the manner of treatment of incorporated persons in them, respectively of the migrant or the victim of trafficking for rehabilitation measures that have to do with: their protection, reintegration program, non-infiltration, social treatment, health care, etc.

\section{Volume and dynamics of expansion of criminal phenomena relating to smuggling of migrants and trafficking in human beings}

The adoption of 1244 Resolution by United Nations Security Council provided grounds for Kosovo to be liberated and to place it under civilian international administration that was accompanied with deployment of military structures of KFOR and civilian structure of UNMIK. The establishment of a new reality was accompanied with creation of a legal and institutional vacuum that was filled on 27 $7^{\text {th }}$ Jul 1999 when the first Regulation 1999/1 was adopted by the United Nations Interim Administration Mission in Kosovo which defined the Authority of Interim Administration in Kosovo. Supplementation of the legal vacuum continued further when on $12^{\text {th }}$ Dec 1999, UNMIK adopted the Regulation 1999/24 in respect of determination of applicable legislation in Kosovo.

The criminal phenomenon relating to the smuggling of migrants and trafficking in human beings as some of the most threatening types of criminality that cause multiple consequences to the society, are quite present in the modern society, including Kosovo. In order to fight, prevent and punish these criminal phenomena, it is necessary to perform a treatment and analysis of fundamental phenomenological and victimological features of criminal offenses relating to smuggling of migrants and trafficking in human beings in Kosovo in the post-war period, respectively after the declaration of Independence of Kosovo ${ }^{1}$, by performing a treatment and analysis through presentation of volume of these criminal offenses, dynamics of commitment, its regional expansion, etc.

The statistics data provided by the Kosovo Agency of Statistics covering the period 2008-2013, indicate that the number of convicted persons for criminal offenses of smuggling of migrants and trafficking in human beings is substantially lower than the number of arrested and charged persons as suspects for the for criminal offenses of smuggling of migrants and trafficking in human beings, where this number has had the following developments during the above-noted time frame ${ }^{2}$ :

\footnotetext{
1 The Kosovo Assembly in its extraordinary meeting of $17^{\text {th }}$ February 2008 , in the capital city of Kosovo in Prishtina, adopted the Declaration of Independence of Kosovo.

2 Jurisprudence statistics for adults and minor for the period 2008, 2009, 2010, 2011, 2012 and 2013, Kosovo Agency of Statistics, Prishtina. https://ask.rks-gov.net/publikimet/cat_view/41-drejtesia
} 


\section{Number of convicted persons for the criminal offenses of smuggling of migrants and trafficking in human beings 2008-2013}

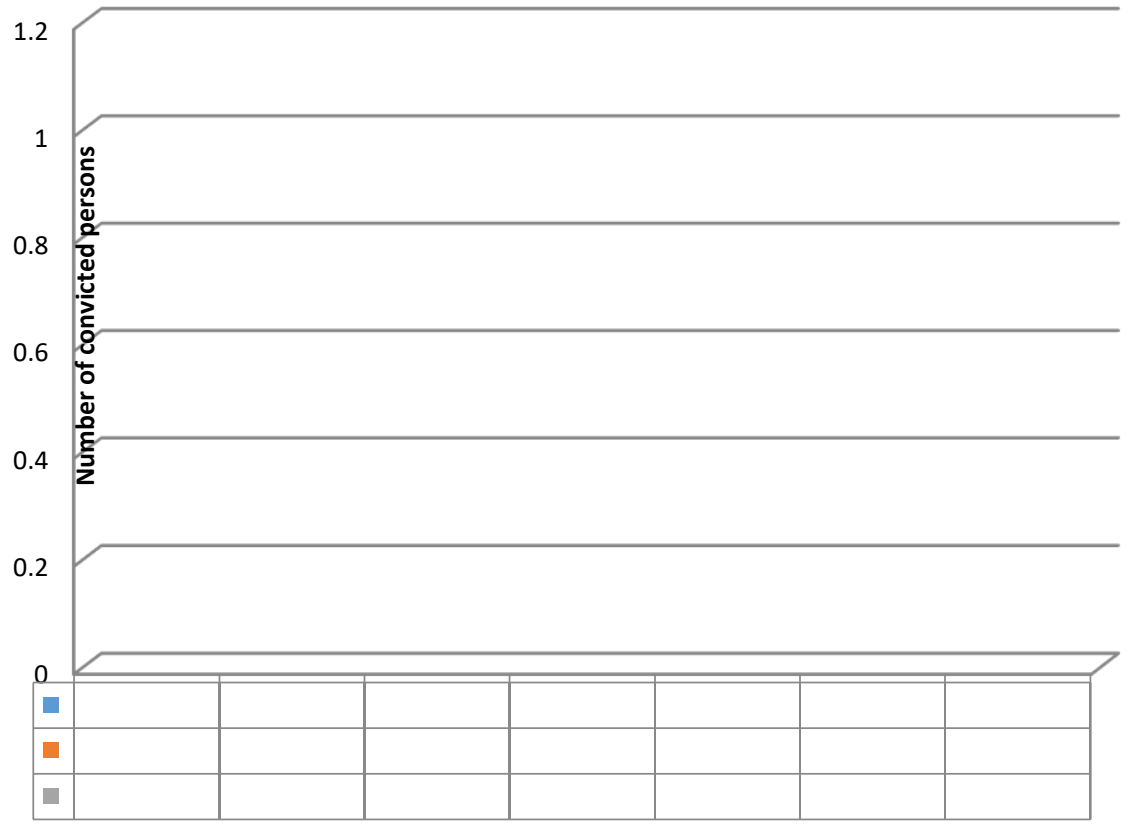

The illustrated data in the above-noted able indicate that the number of convicted persons for committing the criminal offense of trafficking in human beings as set forth in article 139 of the Provisional Criminal Code of Kosovo and article 171 of the Criminal Code of Republic of Kosovo for the period of 2008-2013, was 167 persons or 54 persons more than the number of convicted persons for committing the criminal offense of smuggling of migrants as set forth in article 138 of the Provisional Criminal Code of Kosovo and article 170 of the Criminal Code of Republic of Kosovo for the same period.

\section{Conclusion}

Smuggling of migrants and Trafficking in human beings still continues to be a very concerning criminal phenomenon today in the whole modern society, including the country of Kosovo. According to the above-noted data, we can come to conclusion that the overall self-awareness and professionalism has been on the rise in respect of identification of distinct points between these two criminal offenses, in the institutional and social reaction in fighting, preventing and sanctioning the doers of the criminal offenses of smuggling of migrants and trafficking in human beings, in compliance with the reformation process of organization and expansion of this criminal phenomenon by certain criminal groups. Fortunately, owing to this self-awareness and professionalism of institutions in respect of taking anti-smuggling and anti-trafficking measures, there has been a decrease in the number of victims every year. The necessity to provide a legal ground in response to these modifications came from conventions and other international acts, for instance, the Protocol against Smuggling of Migrants by Land, Sea and Air, supplementing the United Nations Convention against Transnational Organized Crime and the United Nation's Convention against Transnational Organized Crime, the Protocol to Prevent, Suppress and Punish Trafficking in Persons, especially Women and Children, etc. As far as the consequences of these criminal phenomena are concerned, it is normal that they are vast and include such consequences as: psychological, social, ethical, economic and many other ones. 


\section{Literature}

[1] Provisional Criminal Code of Kosovo, Kosovo Assembly, Prishtinë, 2003, which entered into force on 06th Apr 2004. http://www.kuvendikosoves.org/?cid=1,122

[2] Criminal Code of Kosovo, Kosovo Assembly, Prishtinë, 2011, Code No. 04/L-082 which entered into force on 20th Apr 2012. http://www.kuvendikosoves.org/?cid=1,122

[3] Baton Haxhiu. War differently.Prishtina, 2004, p. 69.

[4] Protocol to Prevent, Suppress and Punish Trafficking in Persons, especially Women and Children, the protocol was adopted in November 2000 by the United Nations.

[5] The Protocol against Smuggling of Migrants by Land, Sea and Air, supplementing the United Nations Convention against Transnational Organized Crime and the United Nation's Convention against Transnational Organized Crime.

[6] Declaration of Independence of Kosovo, Kosovo Assembly in its extraordinary meeting of 17th Feb 2008 at the capital city of Kosovo, in Prishtina.

[7] Jurisprudence Statistics for adults and minors 2008, Kosovo Agency of Statistics, Prishtina. https://ask.rksgov.net/publikimet/cat_view/41-drejtesia .

[8] Jurisprudence Statistics for adults and minors 2009, Kosovo Agency of Statistics, Prishtina. https://ask.rksgov.net/publikimet/cat_view/41-drejtesia.

[9] Jurisprudence Statistics for adults and minors 2010, Kosovo Agency of Statistics, Prishtina. https:/lask.rksgov.net/publikimet/cat_view/41-drejtesia.

[10] Jurisprudence Statistics for adults and minors 2011, Kosovo Agency of Statistics, Prishtina. https://ask.rksgov.net/publikimet/cat_view/41-drejtesia.

[11] Jurisprudence Statistics for adults and minors 2012, Kosovo Agency of Statistics, Prishtina. https:/lask.rksgov.net/publikimet/cat_view/41-drejtesia.

[12] Jurisprudence Statistics for adults and minors 2013, Kosovo Agency of Statistics, Prishtina. https://ask.rksgov.net/publikimet/cat_view/41-drejtesia. 